\title{
Mutatis mutandis, architettura e narrazione. L'arte di Guarino Guarini
}

\author{
Carmela Crescenzi
}

Abstract

L'Opera Architettonica è universalmente conosciuta come simulacro, un'icona narrante. È un testo capace di sintetizzare richieste e storie. L'architettura, quale arte, è espressione della conoscenza dell'autore e del pensiero del suo tempo, della sua capacità di pensare, di trasporre e trasferire la sua immaginazione. E un testo che promuove riflessioni secondo individuali e soggettive interpretazioni culturali. Connessioni contingenti al periodo barocco e all'Architettura della Sindone e del San Lorenzo a Torino, mostrano Guarini come un esegeta della narrativa etica e religiosa e un attento interprete del pensiero tridentino.

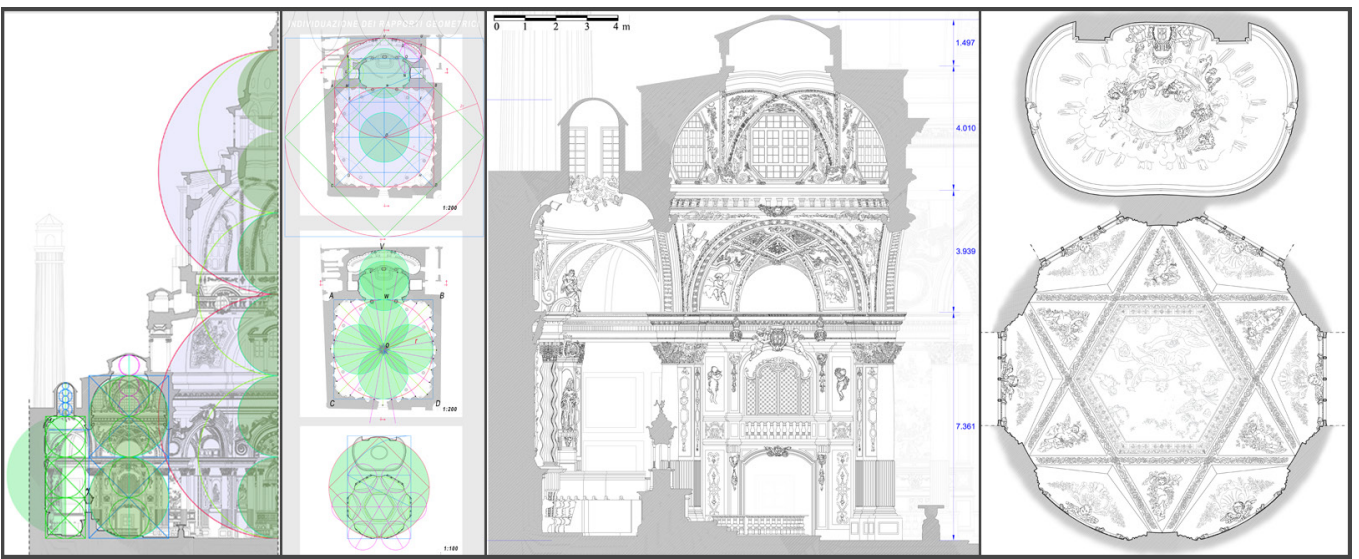




\section{Introduzione alla critica}

Lo studio dell'architettura del G. Guarini, più di altre, è stata nel tempo soggetta a finalizzate interpretazioni o negazione delle stesse, denigrata o enfatizzata. In particolare le sue ultime e coeve opere, la Sindone e il San Lorenzo, sono al centro della speculazione critica esegetica sull'esoterismo insite in esse.

Lo storico dell'arte John Beldon Scott [Beldon Scott 2006] sintetizza i percorsi critici-interpretativi dell'arte Guariniana individuando due rami principali, sintetizzati da Wittkower con "due distinte personalità: una melanconica e misteriosa, l'altra trasparente e completamente razionale" [Wittkower 1958].

Il primo filone si basa sull'interpretazione e analisi critica dei testi, definita da Scott fase Warburchiana, che conduce a una forma tangibile di misticismo religioso favorito fin dal 1887, da C. Gurlitt, e che si è alimentato fino al convegno di Torino del 1968.

"Che cos'è e cosa significa" è la chiave estetica della ricerca Warbuchiana, mentre il "come si pensava dovesse funzionare" è la chiave ermeneutica del secondo percorso di ricerca.

Sostenuta da alcune affermazioni di Giulio. C.Argan [Argan 1957, pp. 6 I -63 ], il ruolo funzionale della geometria nel sistema progettuale comincia ad affermarsi, inizialmente come forma astratta priva di riferimenti iconici, per evolversi in seguito nell'ossimoro di "razionalismo trascendente" [Argan 1968; Tavassi la Greca 1968] e, infine, per svilupparsi in microcosmi simbolici della creazione universale di Dio [Perez-Gomez 1983].

A queste due vie, Scott addiziona la figura di un Guarini, architetto dal pensiero pratico che ha offerto soluzioni ad istanze reali dettate dai bisogni cerimoniali e devozionali sia dei committenti come del pubblico [Klaiber 1993; Dardanello 1993].

Fig. I. La chiusura della volta della Sindone è l'icona architettonica dell'ostensorio. Guarin nella Sindone, con un cambio di scala tale da offuscarne la immediata comprensione, traspone l'arredo sacro in architettura.

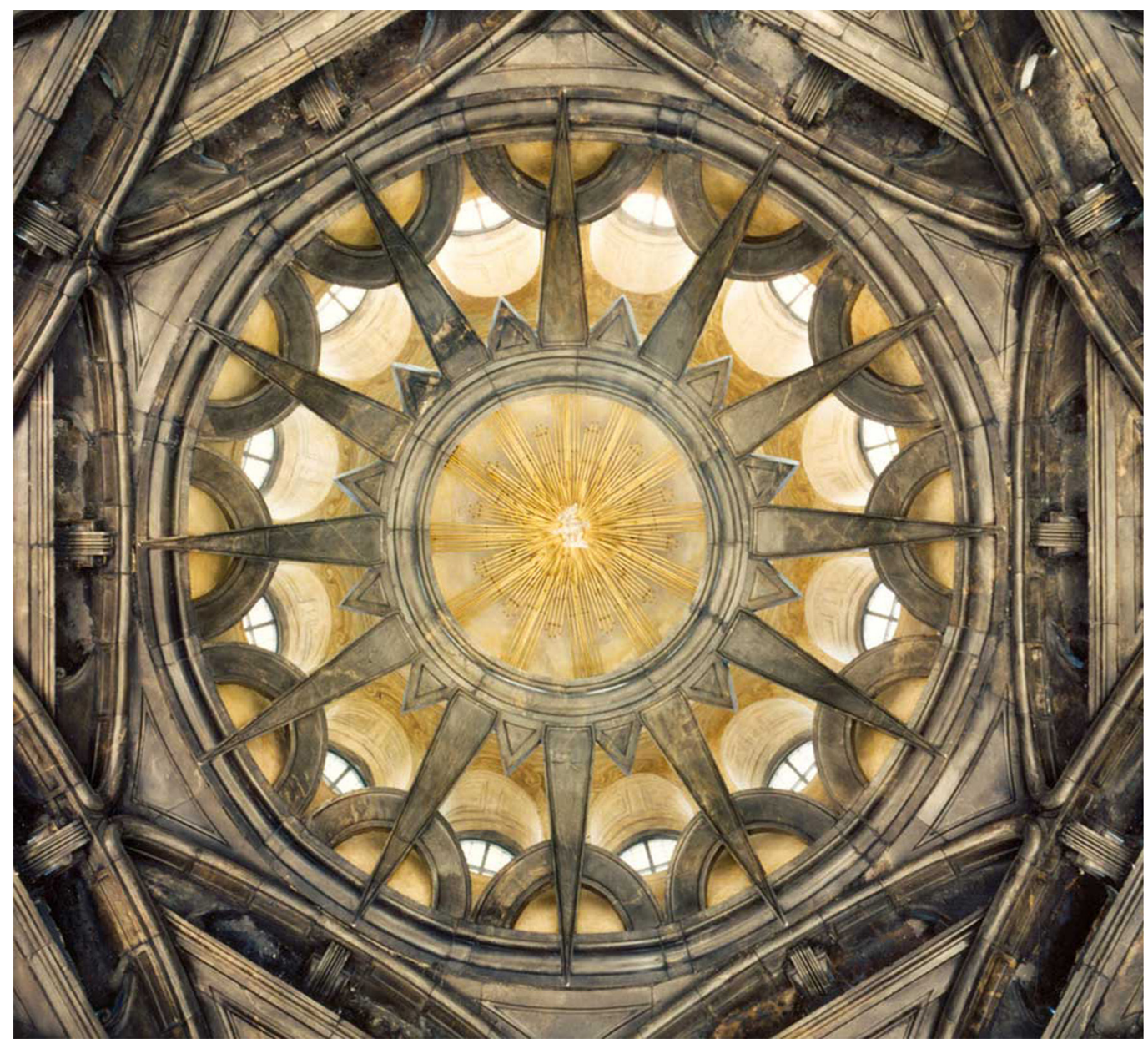




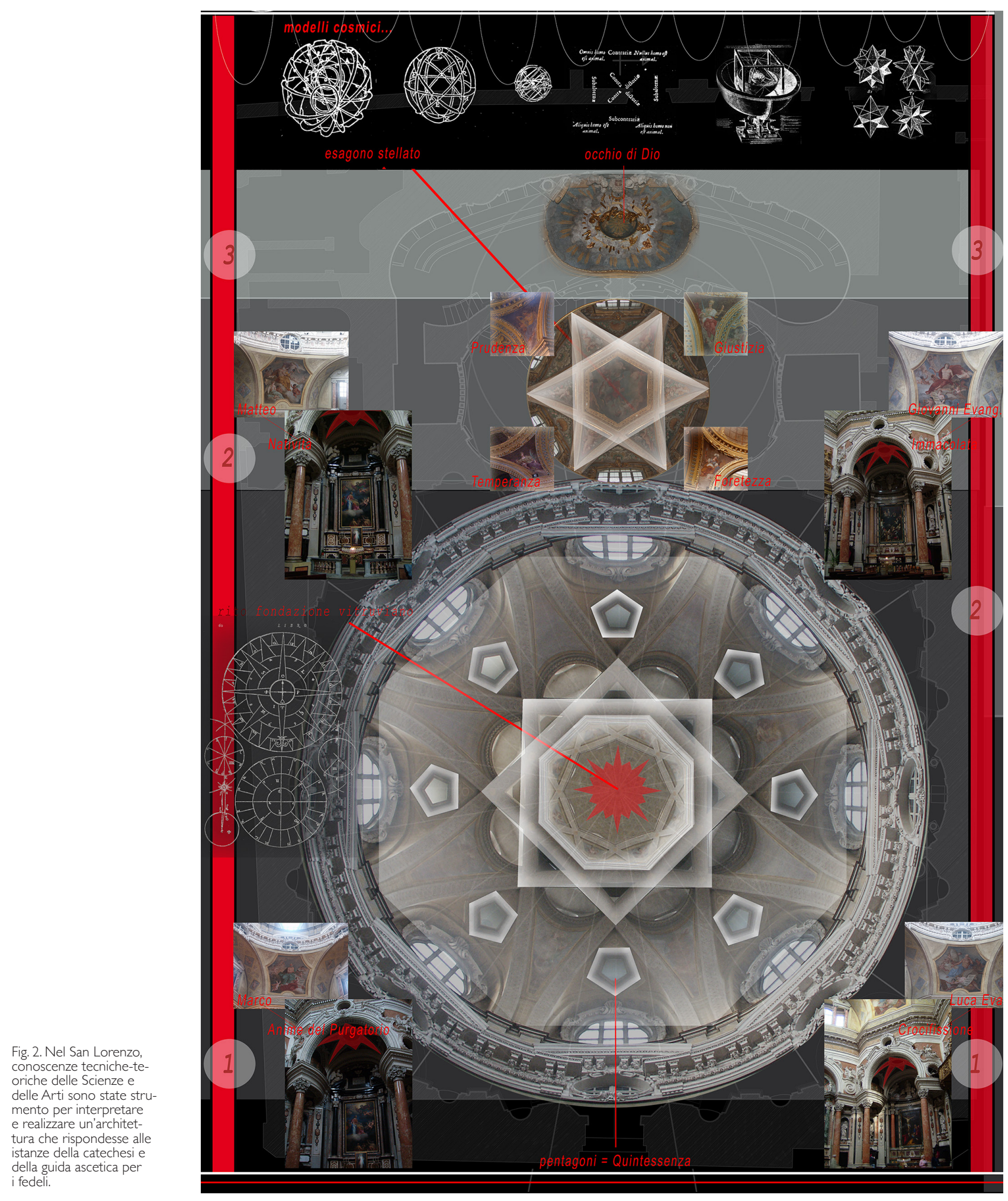


Seguendo questo pensiero, Scott afferma l'originalità espressiva iconografica del Guarini, ma la classifica del tutto convenzionale, affatto esoterica e simboli di superficie.

Tuttavia, egli ritiene che occorra superare i limiti culturali per afferrare il messaggio delle sue cupole, oltre a cogliere l'impatto psicologico sullo spettatore del loro illusionismo, trasposto dalla pittura all'architettura.

II detto di Guarini che l'architettura deve "stupire gl'intelletti" e rendere "gli spettatori atterriti", secondo Scott, trova nella volta della Sindone la sua massima espressione [I].

Fig. 3. Molte delle superfic rispondo alle moderne parametriche e sono costruite con la traslazione di curve (cerchi o ovali) su linee direttrici multiple. Nell'immagine: a) il grande arco dei bracci dell'aula; b) le geometrie delle colonne tortile del Sancata-Sanctorum;

c) pennacchio aperto verso l'alto della volta centrale; d) pennacchi della volta sferoidale de Presbiterio (dalla tesi di

Andrea Magi (a, c) e Giulia Vanni (b, d).
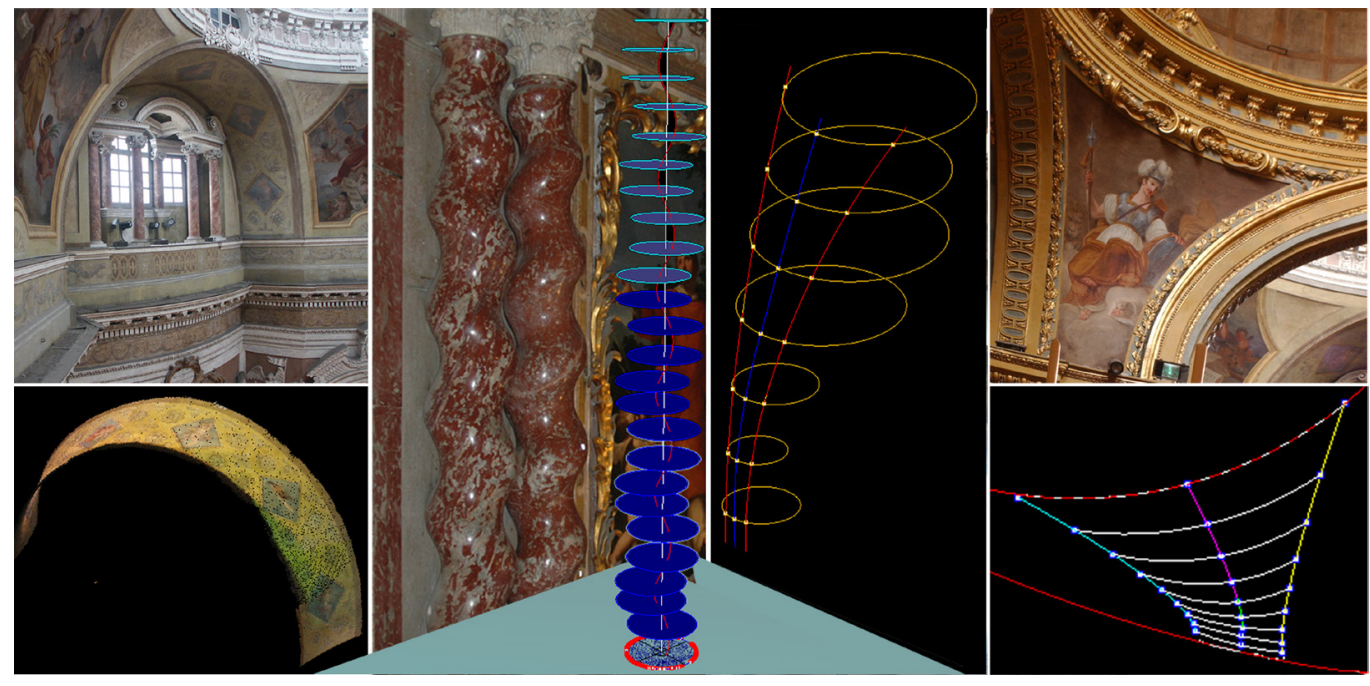

\section{Simulacro e iconicità nella Cappella della Sindone e del San Lorenzo}

Le diverse proposte interpretative e i diversi gradi di lettura, a cui si sono prestate le due ultime opere del Guarini, la Cappella della Sindone e la chiesa del San Lorenzo, rendono queste architetture icone di un linguaggio architettonico mediatico eso/essoterico dove l'iconicità dei diversi apporti, di cui si nutre l'architettura Guariniana, si sovrappongono e si intessono senza soluzione di continuità.

Se "l'esoterismo denota la presunta capacità di accedere al nucleo intimo e unitario di una verità", e "poiché si può parlare di interno solo in rapporto a un esterno, carattere exoterico ed esoterico possono coesistere $[. .$.$] invece di escludersi, possono essere complemen-$ tari" [2].

Alla medesima comunicazione può essere data un'interpretazione essoterica, aperta a tutti, e una più profonda esoterica, appannaggio dei soli iniziati. Tuttavia, la comunicazione che oggi ci appare esoterica, o almeno gran parte di essa, era esplicita ai contemporanei fedeli cattolici [Battisti 1968, p. 109].

Per comprendere meglio il linguaggio iconico degli edifici religiosi, occorre calarsi non solo nel periodo architettonico e nella personalità dei singoli autori-artisti, ma nel pensiero liturgico ad esso contemporaneo.

L'architettura barocca, dopo il Concilio di Trento (I545- I563), svilupperà il desiderio di creazione affermatosi nel contesto di una "riuscita controriforma".

Circostanze storiche-religiose "hanno portato ad un certo umanesimo spirituale all'interno del quale lavorarono uomini che hanno realizzato un insieme coerente di procedimenti originali" [De la Brosse 1979].

Dopo circa 40 anni di guerra, con l'editto di Nantes ( 1598) I'Unione Evangelica da un lato e la Lega Cattolica dall'altro, trovano un certo equilibrio di convivenza. All'Unitarietà della 
Cristianità succede la Città Cattolica. L'Europa della Curia, o anche L'Europa dei Monaci, subentra all'Europa Unita. II Concilio promuoverà gli ordini decentralizzati affinché costruiscano potenti congregazioni regionali. Fra questi vi è, fra i primi fondati ( I524), l'ordine dei Teatini a cui Guarino Guarini appartiene.

Col Giubileo trionfale del 1600 si ha l'affermazione del prestigio e la potenza del pontefice romano, che con il contesto economico favorevole, esprimerà l'effervescente spirito culturale con l'affermazione dell'arte Barocca.

Alla Liturgia Barocca, espressa dalla immutabilità dettata dalle leggi che governano la ritualità della chiesa, si contrappone il culto delle assemblee ecclesiali guidate dalle autorità Episcopali. "l'illustrazione del dogma, il sostegno alla devozione, il senso dell'universalità e della missione e infine la passione per la vita e per la festa" [De la Brosse 1979] sono i quattro temi essenziali dell'umanesimo spirituale del barocco romano.

"ll culto è festa e la cultura Barocca è in prima linea una cultura di festa, manifestazione di tutte le possibilità di un'arte lieta al servizio di un più alto ideale" [Jungmann | 962, p. I 33- I 34]. I Teatini, seguiti da Carlo Borromeo, furono fra i promotori del rapporto dialettico fra liturgia e la festa, strumento del progetto di catechesi ed evangelizzazione, caratterizzato dalla presenza di momenti di forte emozione collettiva.

La vita liturgica, con i suoi arredi (dipinti, statue, tabernacoli) irrompe nelle piazze e vie della città con le sue spettacolari manifestazioni. Le arti quali macchina pedagogica, strumento di accattivante persuasione per il coinvolgimento sensoriale e sentimentale dello spettatore. L'arte, nelle sue rappresentazioni, si fa catechesi.

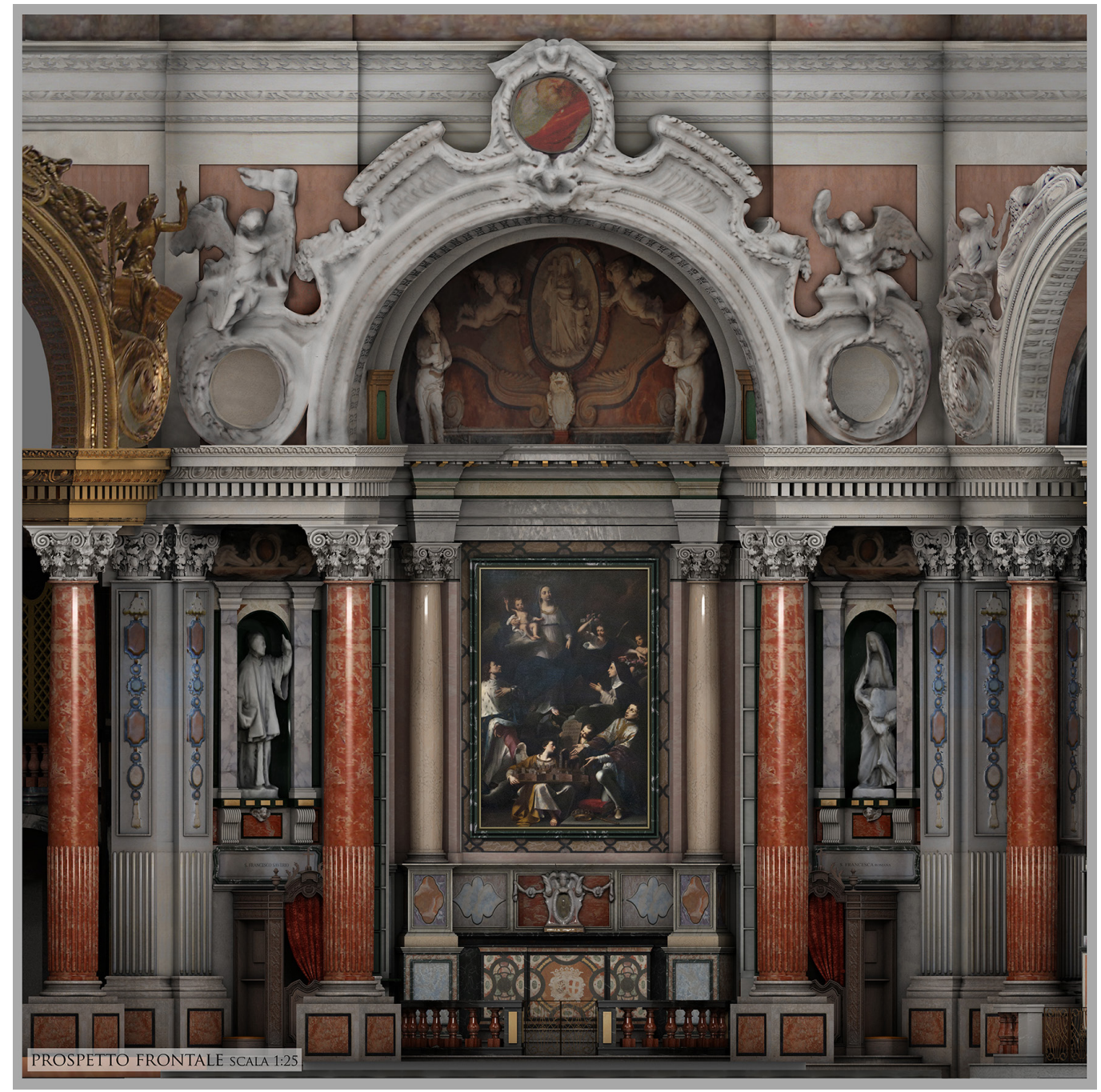


Per i Padri del Concilio l'arte e la ricchezza dei materiali sono strumento per avvicinare l'uomo a Dio [3].

La Chiesa di pietra, magnifica e splendida nella luce dei suoi colori, è lo specchio del cielo in terra, immagine di serenità che si contrappone alle retoriche e terrificanti rappresentazioni dell'inferno e dello stesso purgatorio predicate dagli stessi Ordini.

Esperti della comunicazione e dell'arte di commuovere le coscienze, i Teatini erano in grado di costruire scenografie e rappresentazioni organizzate sulle percezioni sensoriali, attraverso esse muovere la mente ed elevare le coscienze verso Dio.

L'importanza assegnata alle arti, alla cura del luogo di culto (Giberti, Borromeo) fece sì che all'interno dell'ordine si formarono grandissime personalità fra i quali il i padri Paolo Arese (oratore, filosofo, teologo) e Guarino Guarini.

Allinvito del L'arte di predicar bene di Paolo Aresi e al suo appello a delectare i fedeli con nuovi artifici retorici, fa da contrappunto l'Architettura di Garino Guarini.

Aresi, nelle sue lezioni ai suoi chierici chiede di "condir le prediche $[\ldots]$ con $[\ldots]$ concetti peregrini, e di graziato modo di dire" [Aresi I6II, pp. 6, 7]. E che le parole abbiano del "pe-

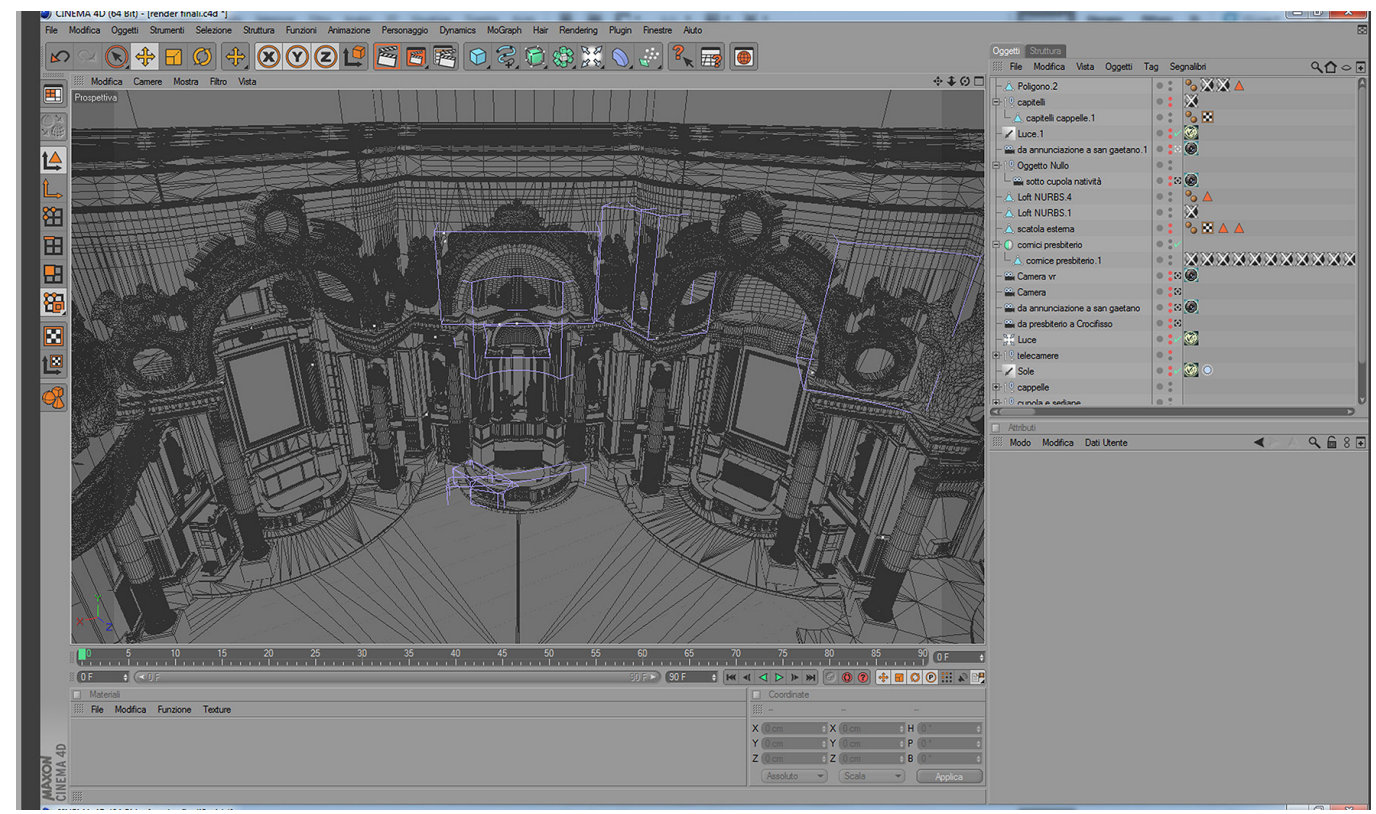

regrino, perché le cose rare e peregrine sono ammirate e la meraviglia porge magnificenza". E che la meraviglia giova in tre maniere: "la prima è col rendere attenti gli ascoltanti perché dall'ammirarsi nasce il desiderio d'intendere le cagioni dell'effetto che ci apporta a meraviglia ed il desiderio genera attenzione per udire ciò che si brama di sapere" [Aresi 161 I, p. I6I]. Quindi l'arte del ben predicare non fine a se stessa ma per offrire al pubblico gli strumenti per apprezzare in tutta la sua portata la parola di Dio.

Concetti assimilati, rimodellati e trasposti nell'arte dal Guarini. La maraviglia della chiesa di pietra deve suscitare attenzione e interesse parimenti alle omelie. L'Architettura sacra deve promuovere nei fedeli un'esperienza di vita interiore e favorire una riflessione sui misteri della fede per un'intima unione con Dio: la sacralità di un luogo collettivo per un individuale percorso spirituale.

Guarini, architetto-filosofo e fine teologo compie la Metis trasformando la narrante omelia in Architettura, simulacro del Verbo di Dio, del Logos, della Luce. E la Luce immanente è la via per condurre a Dio. 


\title{
Dogma e simulacri
}

Quindi il successo della riforma cattolica, si gioca nella pratica quotidiana, con particolare attenzione al coinvolgimento totale dei fedeli nel culto. E Guarini nelle sue due ultime opere dedica e sintetizza le sue conoscenze delle arti nell'illustrazione architettonica, in particolare, di due dogmi avversati dal protestantesimo: La Transustanziazione e il culto di Maria.

Alla negazione della Transustanziazione da parte di Lutero e di Calvino si oppone la spiritualità teatina, e della chiesa cattolica per il culto del Santissimo Sacramento espressa con la valorizzazione dei tabernacoli, fulcro dei presbiteri nelle rinnovate chiese, dalla rivalutazione del rito della Reposizione e dalla processione del Corpus Domini.

Alla negazione del culto Mariano, i protestanti vedevano nella mariologia la "somma di tutte le eresie" [Bertalot 1985, p. I054], la Chiesa Cattolica oppone e proclama i dogmi di Maria Immacolata Concezione e della sua Assunzione al cielo, e ne rafforzava il culto

Guarini nella Cappella della Sindone, con grande forza, traspone l'ostensorio nella scala architettonica della volta. II maneggevole arredo sacro, creato per esporre l'ostia consacrata all'adorazione dei fedeli, diventa un Capocielo a protezione della teca che custodisce il sacro telo. II curato studio della retro illuminazione rende la ostensoria struttura un potenziatore della luce: la luce immanente si trasfigura nella Luce trascendente di Dio.

"ho Theòs phôs estín - Dio è luce" (Giovanni I,5) e l'architettura della luce è l'insolita retorica invenzione che "eziandio" suscita "sorpresa, speranza, passioni e paure" [Ardissimo 200 I, p. 6 I] e ha "del meraviglioso e del paradosso" [Aresi I6 I I, p. I6 I] nella Cappella della Sindone e del San Lorenzo.

\section{La luce è la via}

\author{
"quod lux tum terris, tum caelis insideat, \& utrique regioni dominetur: \\ \& quasi vinculum \& via, caelestibus terrena nectat \\ \& tam sideribus dicatur propria, quam Elementis". \\ [Guarini 1665, p. 397] \\ "Poiché la luce impregna sia la terra che i cieli, \\ e domina su entrambe le regioni, è una sorta di legame e via, \\ che connette le cose terrene a quelle celesti, \\ ed è propia delle stelle quanto degli Elementi" \\ [traduzione di C. Crescenzi]
}

Conoscenze scientifiche, seppur subordinate al pensiero della chiesa del XVI secolo, si fondono con la forza spirituale e mistica che il Guarini volle infondere alle architetture della Sacra Sindone e del San Lorenzo.

Guarini nel suo testo Caelestis mathematicae mostra la sua convinzione nel Sistema Tolemaico. II sistema Tolemaico è funzionale per la Chiesa ed è condizione necessaria e sufficiente per risolvere, con costruzioni geometriche, le relazioni insite nel suo progetto della luce-spazio-architettura.

La luce, costantemente, guida la preghiera e la scoperta del divino nel corso del giorno. L'architettura del San Lorenzo, come un unico corpo, risponde alle leggi solari e lunari. Al progetto dell'orologio solare, guida ascetica e ierofantica, partecipano le finestre dell'intera architettura del San Lorenzo, da quelle poste in facciata a quelle del tamburo del Presbiterio, oltre a quelle dell'aula.

II rilievo del percorso della luce, effettuato in sito nel solstizio estivo, è stato studiato e confrontato nel modello tridimensionale dell'architettura.

Nei primi giorni del solstizio le luci dell'alba illuminano l'ingresso dell'aula e la Cappella dell'Annunciazione. Nell'ora sesta (ovvero le 12,00) il sole illumina contemporaneamente il Dio dei Giorni, rappresentato al disopra della volta delle cappelle della Natività, e il Dio Padre, sulla cappella dell'Immacolata; inoltre un asse punteggiato di luce ravviva la stella, posta al centro del pavimento dell'aula, l'altare la pala di San Lorenzo e la piccola cupola del Sancta Sanctorum. 
Le aperture del presbiterio, alla fine del giorno, illuminano nuovamente la stella e l'ingresso, mentre quelle dell'aula inquadrano la cappella del Crocifisso e rischiarano il Cristo benedicente col globo e la colomba dello Spirito Santo.

Il ciclo del giorno manifesta la venuta di Cristo sulla terra, uomo fra gli uomini, e la sua assunzione in cielo, figlio di Dio e Dio Egli stesso nella unitarietà col Padre.

Alcuni testi Guarini evidenziano l'interesse dell'architetto ai moti lunari. Nel Caelestis mathematicae, pubblicato a Torino nel I683, vari capitoli trattano della Luna; in particolare il Tractatus III Expensio III e IV approfondiscono il de lunaris mense e anno e il de ciclis lunaribus. Lo stesso modello della planimetria dell'aula è assimilabile allo schema delle otto fasi lunari. E la sua attenzione dell'astro trova riferimenti iconici nella falce della luna crescente in mano ad un angelo della cappella dell'Annunciazione o nella iconografia della Madonna Immacolata. II mese lunare, o sinodico, è ciclico ogni 19 anni (ciclo Metonico). Per l'analisi si è scelto il periodo Metonico contemporaneo alla costruzione della chiesa e di ciascun mese alcune ricorrenze legate al culto Mariano e gli equinozi e solstizi e solo nelle ore notturne.

Ad esempio, la verifica virtuale degli eventi lunari, nella disamina dell'anno 1671 mostra che il 17 maggio, giorno di Pentecoste e di Lunistizio superiore, la Luna crescente illumina l'evangelista San Luca, posto sulla Cappella dell'Annunciazione; sulla decorazione dell'arco della Cappella, vi è un angelo che porta una luna crescente come simbolo di prosperità.

Nel giorno della Natività, 25 dicembre, la luna - ultimo quarto illumina il vano nascosto della cappella del Crocefisso.

Nello stesso anno, la luna evidenzia il giorno del concepimento come uomo, il giorno del passaggio della vita terrena a quella divina, e il giorno della trasfigurazione a figlio di Dio.

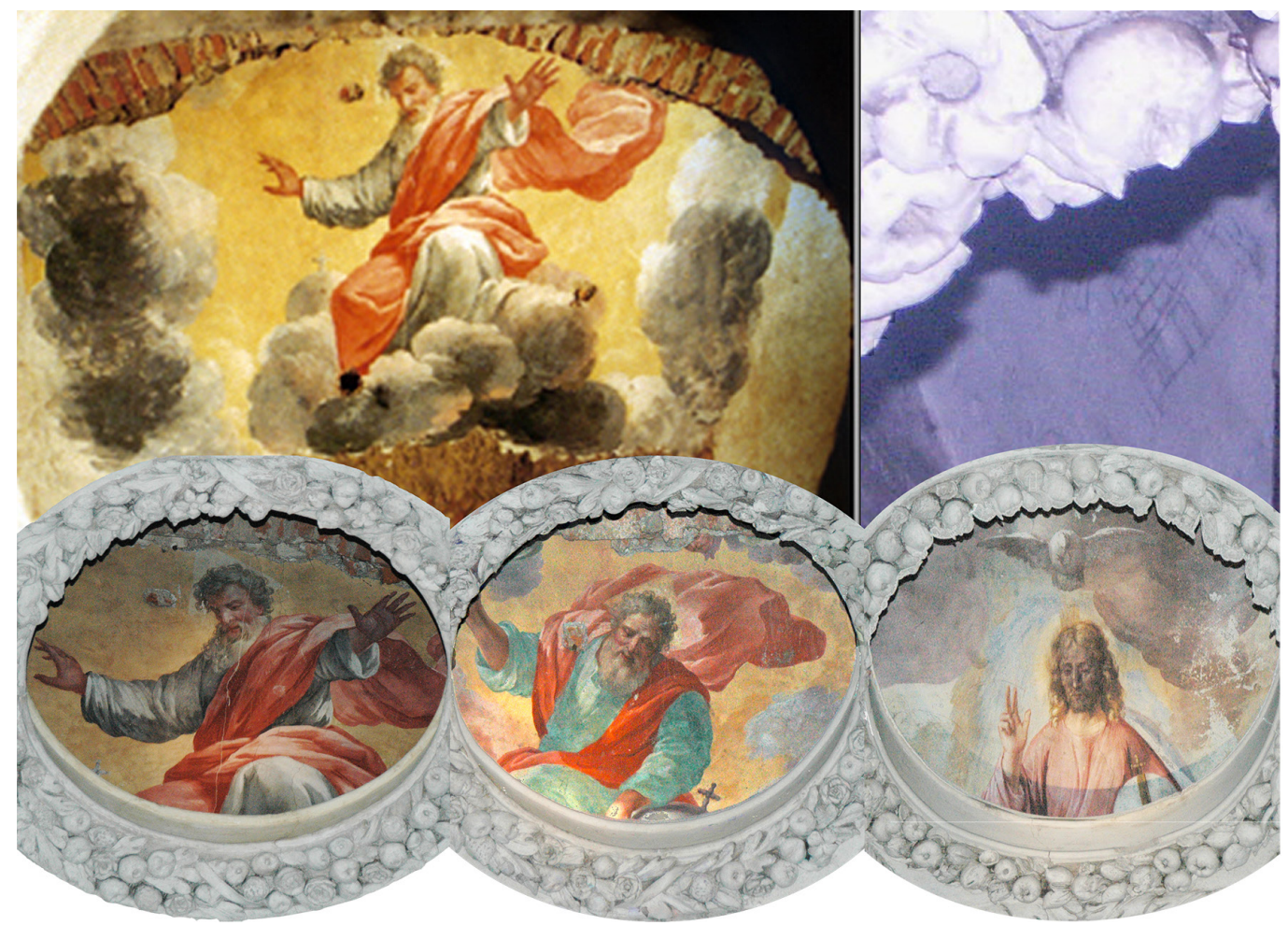

\section{Conclusioni}

Guarini, esegeta della lezione vitruviana, interpreta l'architettura quale sintesi delle arti, manifesto-icona per la tensione religiosa verso il Divino; ermeneuta della reductio artium di Bonaventura da Bagnoregio, manifesta l'unitarietà delle arti "sotto la luce della verità rivelata" ed elegge l'architettura a suo simulacro. 
E l'aula è il trionfo di Prometeo. Teoria e Tecnica per realizzare una sostanziale Metis delle consolidate strutture murate in performanti strutture di Luce, una Metis della paradossale narrazione orale in un incredibile evocativo edificio.

Teoria e Tecnica per conseguire una imperitura Mnemosine attraverso la empirica narrazione (dal suggerimento della purezza di Maria e della grandezza di Maria alla nascita e morte di Cristo) per sostenere costantemente la trascendente Verità dei dogmi di fede con la sapiente rappresentazione virtuale della Luce trascendente attraverso i fenomeni della immanente luce.

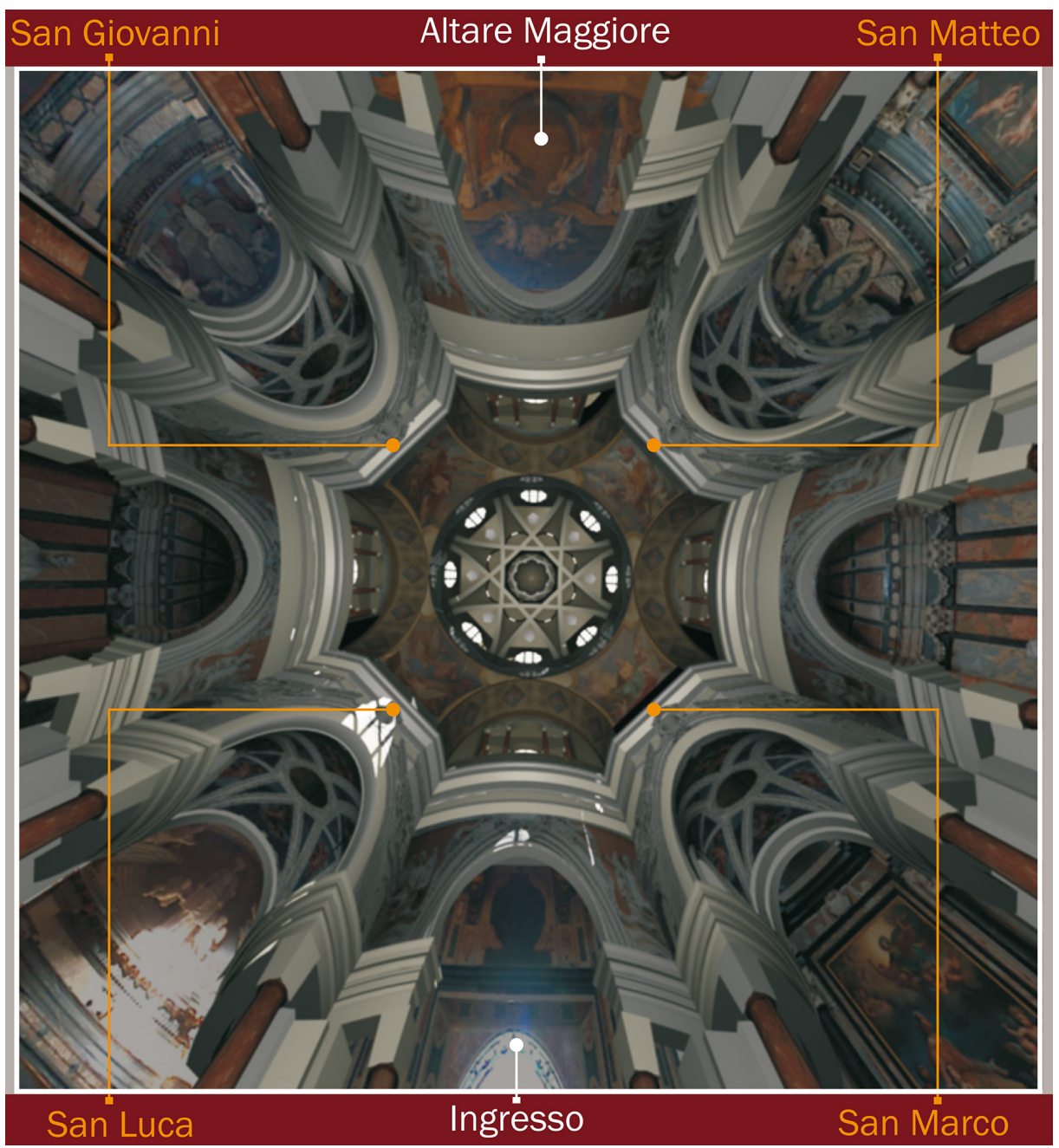

\section{Note}

[I] Per la bibliografia dei riferimenti del I paragrafo si veda: Beldon Scott 2006, pp. I I7-I 22.

[2] <https://it.wikipedia.org/wiki/Esoterismo>

[3] Le citazioni e i riferimenti da Frascarelli "drappi [... cose preziose per servizio ciel Culto Divino, [...] gli ornamenti pretiosi delle chiese [...] per accrescere ne Popoli la pietă, e la veneratione verso le cose di Dio. "Sia pure angusta la casa, povera la cella, scarso il vitto, lacero il vestito, ma sia ricca, sia ornata la chiesa" [Frascarelli 200 I, p. I6; Forti I 686, pp. I 85- I 86.]. Questo il pensiero di San Gaetano da Thiene espressamente condiviso da Carlo Borromeo in una sua omelia pronunciata ad Olginate nel 1583 "Almeno nel culto foste splendidi, o figli, [... Perché piuttosto non togliamo qualche cosa dalle nostre mense, onde poter abbellire la casa di Dio e ampliare la nostra madre? [...] I vasi sacri sarebbero d'argento e d'oro, gli altari coperti di addobbi preziosi". E Johannes Molanus, nel I570, scrive:" 'La chiesa è un'immagine del cielo sulla terra. Dio la riempie per intero. Come non adornarla di ciò che v'è di più prezioso?" [Molanus 1570, p. 24] 


\section{Riferimenti bibliografici}

Ardissino Erminia (200 I). II Barocco e il Sacro. Città del Vaticano: Libreria Editrice Vaticana, p. 6I.

Aresi Paolo (|6| I). Arte di predicar bene.Venezia: Ciotti e Compagni, pp. 6, 7.

Argan Giulio Carlo (1957). L'architettura barocca in Italia. Milano: Garzanti, pp. 6I-63.

Argan Giulio Carlo (1970). La tecnica del Guarini. In Guarino Guarini e l'internazionalità del Barocco. Atti del Convegno internazionale promosso dall' Accademia delle Scienze di Torino. Torino, 30 settembre -5 ottobre, 1968. Torino: Accademia delle Scienze, voll, pp. 35-46.

Battisti Eugenio (1968). Schemata nel Guarini. In Guarino Guarini e l'internazionalità del Barocco:Atti del Convegno internazionale promosso dall' Accademia delle Scienze di Torino. Torino, 30 settembre -5 ottobre, 1968. Torino: Accademia delle Scienze, vol I, p. 109.

Beldon Scott John (1995). Guarino Guarini's Invention of the Passion Capitals in the Chapel of the Holy Shroud. In Journal of the Society of Architectural Historians, Vol. 54, N. 4, University of California Press: Berkeley, p. 4l 8-445.

Beldon Scott John (2006). "Stupire gl'intelletti”: Guarini e il significato dell'architettura. In Dardanello Giuseppe, Klaiber Susan, Millon Henry A. (a cura di). Guarino Guarini.Venezia: Centro Internazionale di Studi di Architettura Andrea Palladio, pp. I 17 - 12 I.

Crescenzi Carmela (2007). II modello e la complessità architettonica del San Lorenzo di Guarino Guarini. In: Docci Mario (a cura di). Metodologie integrate per il rilievo, il disegno, la modellazione dell'architettura e della città. Roma: Gangemi, pp. I 0 I - 04.

Crescenzi Carmela (2007). II San Lorenzo di Guarino Guarini. Rilievo integrato: interpretazione dei dati e rappresentazione (I). In Mandelli Emma (a cura di). Dati, informazione, Conoscenza. Metodi e tecniche integrate di rilevamento. I modelli tridimensionali, la costruzione e trasmissione dei dati. Firenze: Alinea, pp. 73-82.

Crescenzi Carmela (20 I0). II San Lorenzo di Guarino Guarini. Rilievo integrato: interpretazione dei dati e rappresentazione (II). In Chiavoni Emanuela, Paolini Priscilla (a cura di). Metodi e Tecniche Integrate Di Rilevamento Per La Realizzazione Di Modelli Virtuali Dell'architettura Della Città. Roma: Gangemi Editori, pp. 266-27I.

Crescenzi Carmela (20 I0). La Real Chiesa di San Lorenzo. L'architettura della struttura. In: Mandelli Emma,Velo Ulivia. Il modello in architettura: tra cultura scientifica e rappresentazione. Firenze: Alinea, pp. 83-92.

Crescenzi Carmela et al. (2005). The survey of the baroque interior of the San Lorenzo Church in Turin. In: XX International Symposium. International cooperation to save the world's cultural Heritage. The International Archives Of The Photogrammetry, Remote Sensing And Spatial Information Sciences, 26 september/l october 2005, Torino: CIPA vol. I, pp. $203-208$.

Dardanello Giuseppe ( 1993). La scena Urbana in Torino, I 675- I 699. In Giovanni Romano. Strategie e conflitti del Barocco. Torino: Cassa Risparmio Torino.

De la Brosse Olivier (1979). Lo spirito del barocco. Le Message Spirituel des Artistes à Rome. Roma: Centre Saint Louis de France. <http://www.gliscritti.it/arte_fede/barocco.htm>.

Frascarelli Dalma (200 I). Arte e Controriforma: l'altare maggiore nelle Instructiones. Fabricae et supellectilis ecclesiasticae di Carlo Borromeo. In Marco Gallo. Cardinali Di Santa Romana Chiesa collezionisti e mecenati. Roma: Edizioni dell'Associazione Culturale Shakespeare And Company, Vol. I, pp. 24-37.

Guarini Guarino (1675). Compendio sulla sfera celeste. Torino: Giorgio Colonna.

Guarini Guarino (1683). Caelestis mathematicae pars prima (secunda), in qua leges antiquae, et nouae temporum. ExTypogrphia Ludouici Montiae.

Guarini Guarino (1737). Architettura civile. Appresso Gianfrancesco Mairesse. Torino.

Guarini Guarino (1 665). Placita Philosophica. Paris: edizioni Thiery.

Gurlitt Cornelius ( 1887). Hichte dts Barockstilu in Italien. Ebner \& Seubert: Stuttgart.

Jungmann Josef Andreas (1962). La vita liturgica nel Barocco. In Jungmann Josef Andreas. Eredità liturgica e attualità pastorale. Roma: Paoline, pp. | $33-145$

Klaiber Susan (1993). Guarino Guarini's Theatine Architecture. New York: Columbia University.

Pérez-Gómez Alberto (1983). Architecture and the Crisis of Modern Science. Cambridge:The MIT Press.

Tavassi La Greca Bianca (1968). La posizione del Guarini in rapporto alla cultura filosofica del tempo. In Carboneri Nino, Tavassi La Greca Bianca. Guarino Guarini, Architettura Civile. Milano: Edizioni il Polifilo, pp. 440-455.

Wittkower Rudolf (1972). Arte e Architectura in Italia l 600- I 750. Einaudi:Torino 1972 (ed. originale 1958).

\section{Autore}

Carmela Crescenzi, Università di Firenze, carmela.crescenzi@unifi.it

Per citare questo capitolo: Crescenzi CAamela (2020). Mutatis mutandis, architettura e narrazione. L'arte di Guarino Guarini/Mutatis mutandis, architecture and narrative. The Guarino Guarini skill. In Arena A., Arena M., Brandolino R.G., Colistra D., Ginex G., Mediati D., Nucifora S., Raffa P. (a cura di). Connettere. Un disegno per annodare e tessere. Atti del $42^{\circ}$ Convegno Internazionale dei Docenti delle Discipline della Rappresentazione Connecting. Drawing for weaving relationships. Proceedings of the 42 th International Conference of Representation Disciplines Teachers. Milano: FrancoAngeli, pp. $1119-1138$ 


\title{
Mutatis Mutandis, Architecture and Narrative. The Guarino Guarini Skill
}

\author{
Carmela Crescenzi
}

\section{Abstract}

Architecture is universally known as a simulacrum; it is a narrative icon. It can synthesise inquiries and tales through shapes and structures. Architecture, as an art, is an expression of the author's knowledge, of his ability to think, to apply and transfer his imagination. It is a text that promotes reflections according to individual and emotional cultural interpretations. The connection to the Baroque period and the Architecture of San Lorenzo in Turin represents Guarini as an exegete of ethical and religious narrative, and a careful interpreter of the Tridentine think.

\section{Keywords}

Guarino Guarini, archaeoastronomy, iconography-architecture, representation-architecture, cultural heritage.

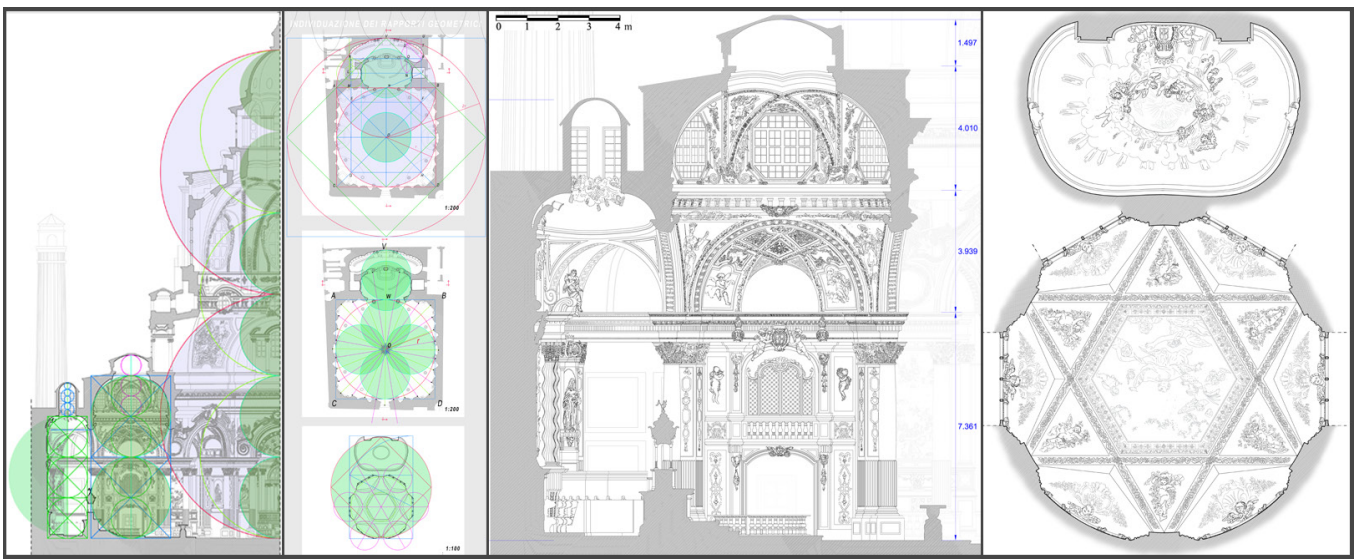




\section{Introduction to criticism}

The study of architecture by G. Guarini, more than others, has been the subject of a refined interpretation or denial of the same, it been denigrated or emphasised. In particular, the Shroud and the San Lorenzo Chapel, two of his last works, are in the centre of critical exegetical speculation on esotericism inherent in them.

The art historian John Beldon Scott [Beldon Scott 2006] summarises the critical-interpretative paths of Guarini's art. It identifies two main branches, which Wittkower has sum-up with "two distinct personalities: one melancholic and mysterious, the other transparent and completely rational" [Wittkower 1958].

The first strand is based on the interpretation and on the critical analysis of texts, defined by Scott as Warburchian. Since 1887, this leads to a tangible form of religious mysticism, favoured by C. Gurlitt, and which it was nurtured until the 1968 Turin conference.

The "what it is and what it means" is the hermeneutical key of the Warbuchian research, while the "as it was thought should work" is the esthetical key of the second research path. The functional role of geometry in the design system, supported by some of Giulio C. Argan's [Argan 1957, pp. 6I-63] statements, spread initially as an abstract form without any iconic references, and they continue to evolve into the oxymoron of "transcendent rationalism" [Argan 1968; Tavassi la Greca 1983]. Finally, they develop into microcosms symbolic of the universal creation of God [Perez-Gomez 1983].To these two ways, Scott adds the figure of an architect Guarini from rational thought who offered solutions to real demands dictated by the ceremonial and devotional needs of both the clients and the public [Klaiber 1993; Dardanello 1993].

Fig. I. The closure of the vault of the Shroud chapel is the monstrance architectural iconic silhouette. G. Guarini in the Shroud transposes the sacred furnishings into architecture the change of scale obscures the immediate understanding of its transformation.

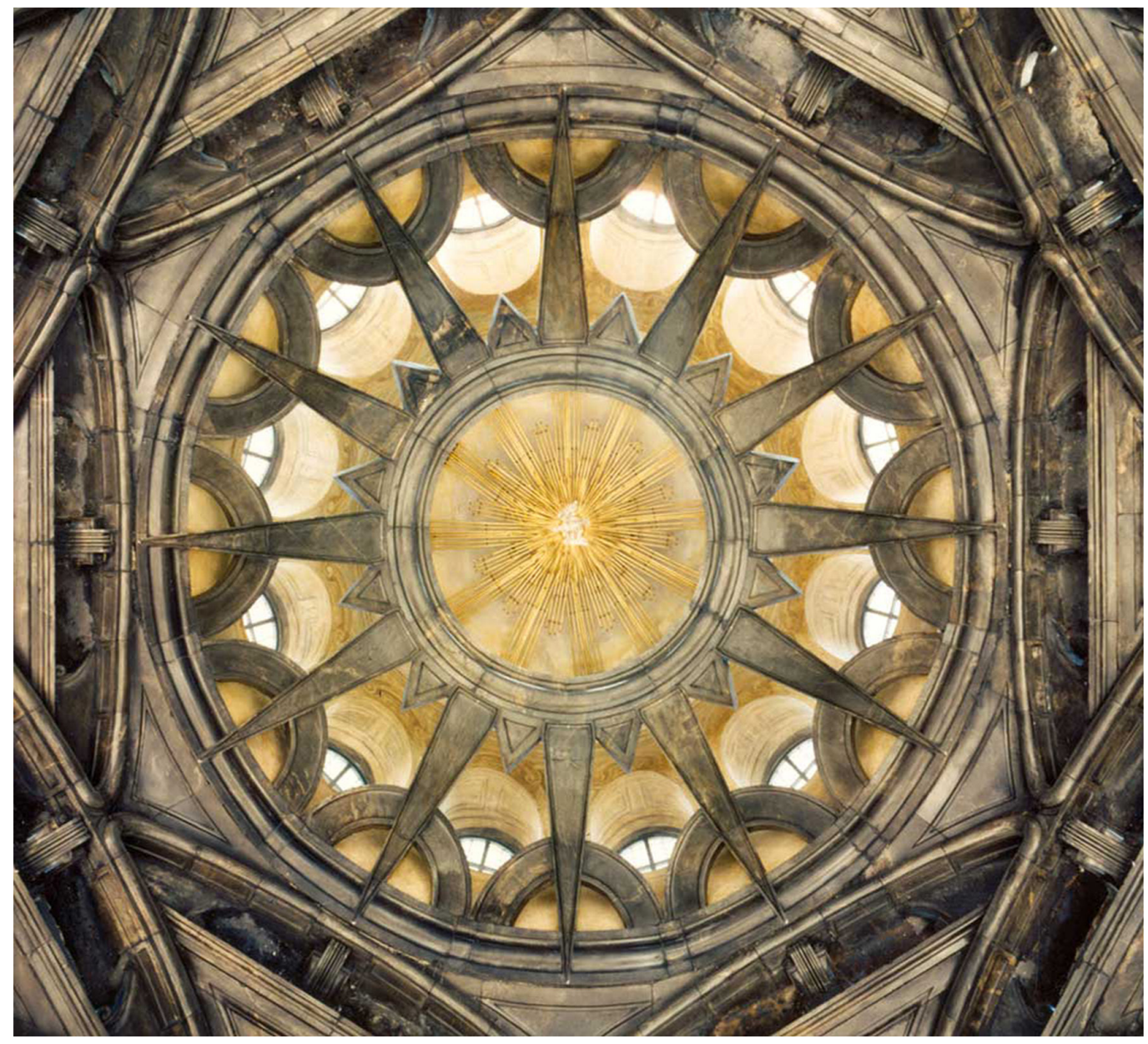




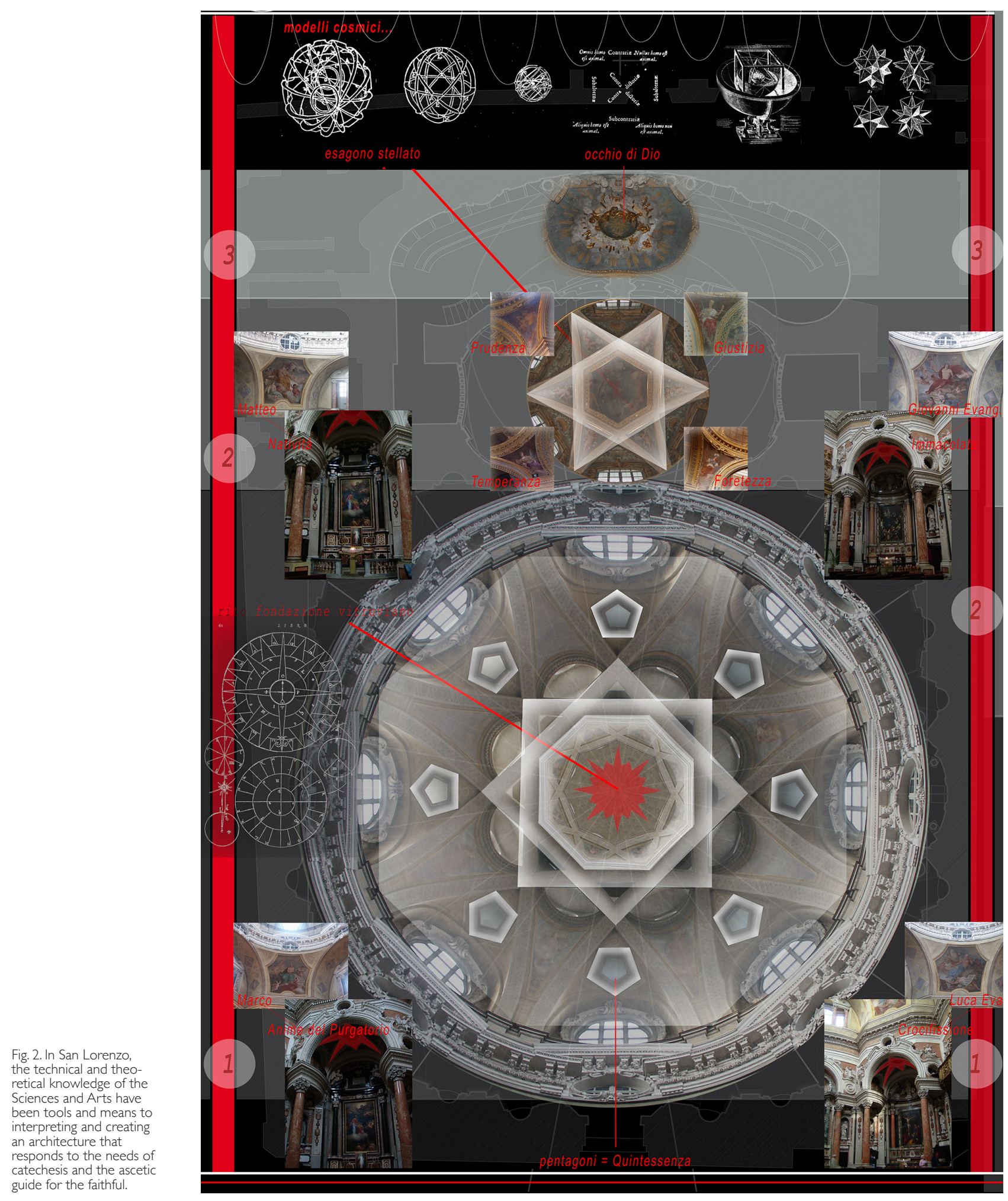


Besides these principles, Scott affirms Guarini's iconic expressive originality; however, he defines it as very conventional, instead of esoteric and with surface symbols.

Anyway, he believes that we should overcome cultural limits to grasp the message of his domes, as well as see the psychological impact on the viewer of their illusionism, moving from painting to architecture.

The quote of Guarini that architecture must "amaze intellects" and make "spectators terrified", according to Scott, he finds its highest expression in the vault of the Shroud Chapel [I] .

Fig. 3. Many of the surfaces respond to parametric surfaces, curves with variable radius translate (circles or ovals) on multiple guidelines. In the image: a) the broad arch of the classroom arms; b) the geometries of the Solomonic columns of the Sancta-Sanctorum: c) pendentive open: c) pendentive open towards the top of the central vault; d) plumes the Preshtery (thesis by the Presbytery (thesis by Andrea Magi (a, c) and Giulia Vanni (b, d).
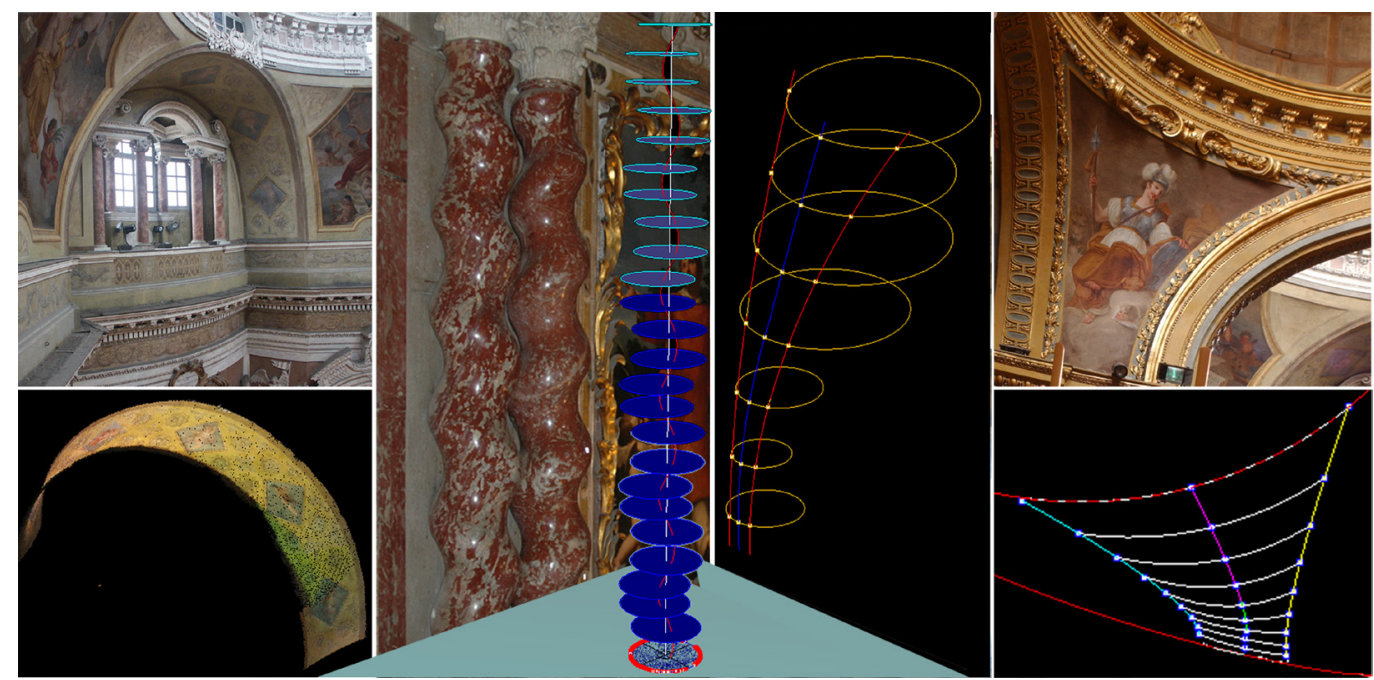

\section{Simulacrum and Iconicity in the Chapel of the Shroud and San Lorenzo}

The different interpretative proposals and the varying degrees of reading, to which have been subjected the Chapel of the Shroud and the church of San Lorenzo, make these architectures icons of an eso-exoteric media architectural language. In them, the iconic nature of the various contributions, of which the Guarini architecture is nourished, overlap and become seamlessly interwoven.

If "esotericism denotes the presumed ability to access the intimate and unitary nucleus of a truth", and "since someone can speak of an interior only concerning an external, exoteric and esoteric character can coexist $[. .$.$] instead of being excluded. They can be comple-$ mentary" [2].

Furthermore, the same communication can acquire an exoteric interpretation, open to all, and a more in-depth esoteric understanding, a prerogative of only initiates.

However, the communication that today appears to us as esoteric, or at least a large part of it was explicit to contemporary Catholic believers [Battisti 1968, p. I09].

To understand the iconic language of religious buildings deeply, we need to be the only ones in the architectural period and the personality of individual authors, but contemporary liturgical thought. After the Council of Trent (1545-1563), the Baroque architecture will develop the desire for creation that became established in the context of a "counter-reform success".

Historical-religious circumstances "have led to a certain spiritual humanism in which men worked who made a coherent set of original procedures" [De la Brosse 1979].

After about 40 years of war, the Evangelical Union and the Catholic League find a positive balance of coexistence with the Edict of Nantes (1598). The Catholic City succeeded in the unity of Christianity. The Europe of the Curia, or even the Europe of the Monks, takes 
over from United Europe, and the Council will promote decentralised orders to build influential regional congregations. Among these, the first founded (1524) is the order of the Teatini to whom Guarino Guarini belongs.

With the triumphant Jubilee of the 1600s, we have seen the success of the prestige and power of the Roman Pontiff, who with the favourable economic context, will express the effervescent cultural spirit with the affirmation of Baroque art. The Episcopal authorities led the worship of ecclesial assemblies. These are opposed to the Baroque Liturgy, expressed by the immutability dictated by the laws that governed the rituality of the church.

"The illustration of the dogma, the support for devotion, the sense of universality and mission and finally the passion for life and celebration" [De la Brosse] are the four essential themes of the spiritual humanism of the Roman Baroque.

"Worship is a feast, and Baroque culture is at the forefront of a festive culture, it is the manifestation of all the possibilities of a happy art at the service of a higher ideal" [Jungmann 1962, p. 133-134].

The Theatines, followed by Carlo Borromeo, was among the promoters of the dialectical relationship between the liturgy and the feast. The feasts were an instrument of the catechesis and evangelisation project. Moments and scenes of strong collective emotion characterised the sacred celebrations.

Liturgical life, with its furnishings (paintings, statues, tabernacles), broke into the squares and streets of the city with its spectacular manifestations. The arts were a pedagogical machine,

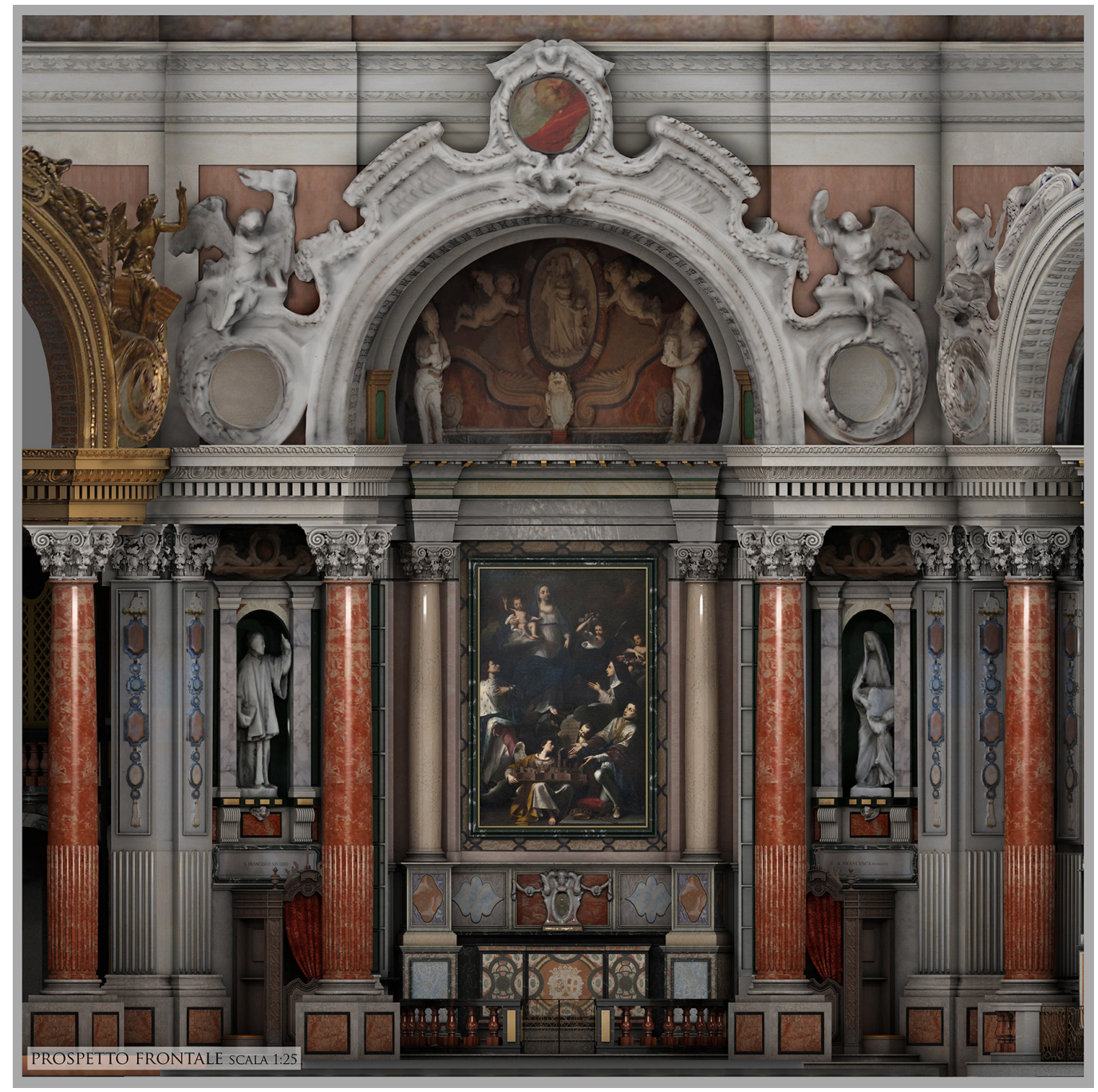


an instrument of captivating persuasion for the sensory and soulful involvement of the spectator. In all its representation forms, art became catechesis.

For the Fathers of the Council, art and the wealth of materials are instruments to bring humanity closer to God [3].The stone Church, magnificent and splendid in the light of its colours, is the mirror of heaven on earth, an image of serenity that contrasts with the rhetoric and terrifying representations of hell and purgatory preached by the same Orders.

The Theatines, experts in the arts to spread and move consciences, were able to build scenographies and representations organised on the sensory perceptions of humanity and through them move the mind and raise consciences towards God. Great personalities, including the fathers Paolo Arese (speaker, philosopher and theologian) and Guarino Guarini, were formed within the order for the importance assigned to the arts, to the care of the place of worship.

At the invitation of Paolo Aresi The art of preaching well and his appeal to delectare (amuse), the faithful with new rhetorical artifices, the Guarino Guarini Architecture is a counterpoint.

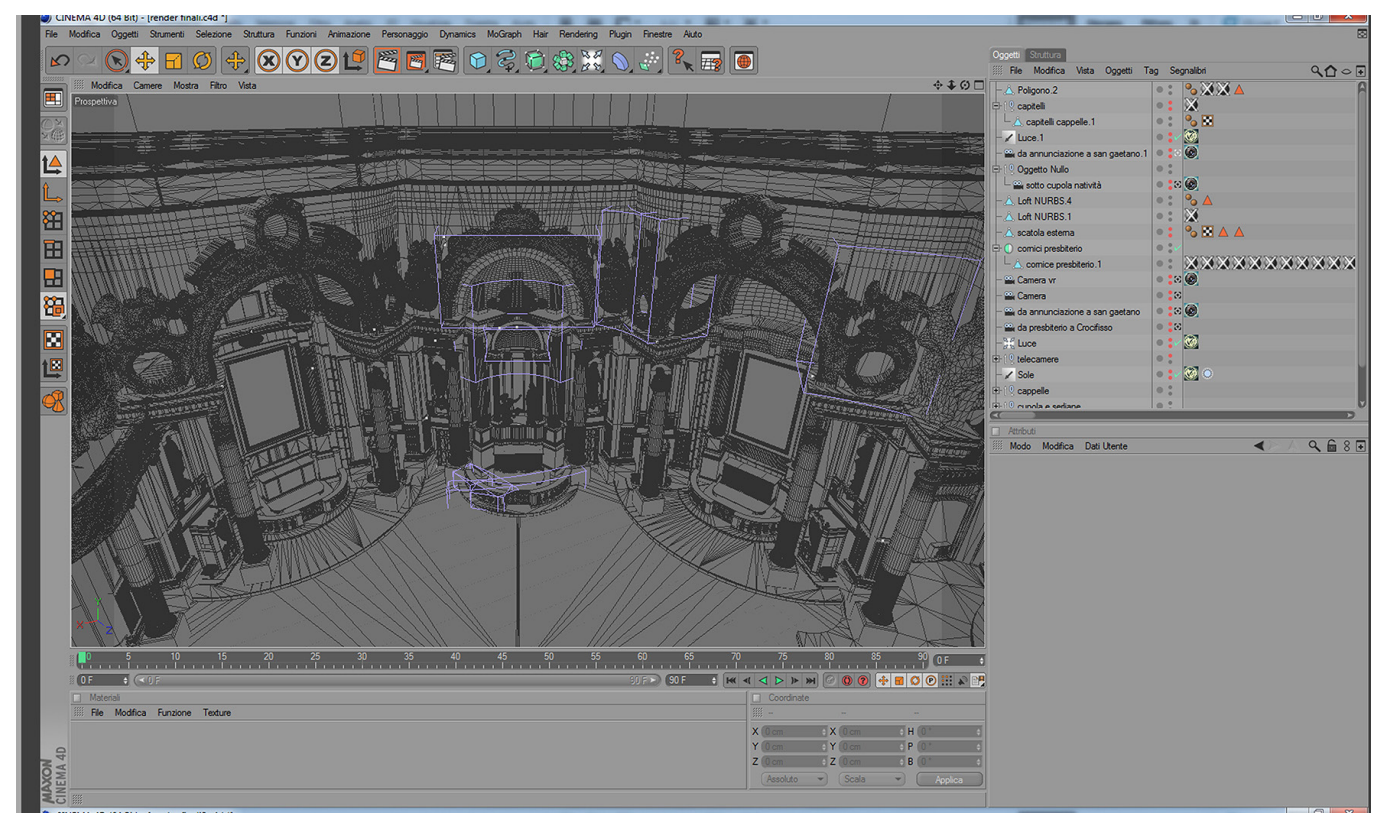

Father Aresi, in his lectures to his clerics, asks to "share the sermons [...] with [...] peregrini concepts, and in a graceful way of saying" [Aresi I6II, pp. 6, 7]. Again, that the words have the "peregrino because rare and peregrine things are admired, and wonder brings magnificence". Furthermore, that wonder benefits three ways: "The first is by making the listeners attentive because from admiring the desire to understand the reasons for the effect it brings us in wonder, and the desire generates attention to hear what you crave to know" [Aresi $16 \mathrm{I}$, pp. $\mid 6 \mathrm{I}$ ]. Therefore, the art of good preaching offers the public the tools to appreciate the word of God in its full extent.

Concepts assimilated, reshaped and transposed into art by Guarini. The wonder of the stone church must arouse attention and interest like homilies. Sacred architecture must promote an experience of the inner life in the faithful and encourage reflection on the mysteries of faith for an intimate union with God: the sacredness of a collective place for an individual spiritual journey.

Guarini, architect-philosopher and excellent theologian accomplishes the Metis by transforming the narrative homily into Architecture, a simulacrum of the Word, of Logos, of Light. The pervasive Light is the way to lead to God. 


\section{Dogmas and simulacra}

Therefore, the success of the Counter-reformation is played out in daily practice, with particular attention to the total involvement of the faithful in worship. In his last two works, Guarini dedicates and synthesises his knowledge of the arts in architectural illustration, in particular, of two dogmas opposed by Protestantism:Transubstantiation and the cult of Mary. Theatine and Catholic Church spirituality for the worship of the Blessed Sacrament are opposed to the denial of the Transubstantiation of the Reformists. The enhancement of the tabernacles, the re-evaluation of the ritual of the Reposition and the Corpus Christi procession are the tools for the dissemination of the cult.

To the denial of the Marian cult, the Protestants saw in Mariology the "sum of all heresies", the Catholic Church opposed and proclaimed the dogmas of Mary Immaculate Conception and his Assumption to heaven, and strengthened its worship [Jungmann 1985, p. 1054].

Guarini in the Shroud Chapel, with great force, transposes the monstrance into the architectural scale of the vault. The functional sacred furniture, created to expose the host consecrated to the worship of the faithful, becomes a Capocielo to protect the display case that houses the holy cloth. The careful study of the backlighting makes the monstrance structure a light enhancer: the immanent light is transfigured into the transcendent Light of God. "Ho Theòs phôs estín - God is light" (Giovanni I,5), and for Guarino Guarini, the architecture of light is the unusual rhetorical invention that also arouses "surprise, hope, passions and fears" [Ardissino 200 I, p. 6I] to control and has "wonderful and of the paradox" [Aresi I6II, p. 161] in the Shroud and San Lorenzo chapel.

\section{The light is way}

"quod lux tum terris, tum caelis insideat, \& utrique regioni dominetur;
\& quasi vinculum
$\&$ via, caelestibus terrena nectat,
$\&$ tam sideribus dicatur propria, quam Elementis".

[Guarini 1665, p. 397]

"The light impregnates both the earth and the heavens and dominates both regions. Therefore, it is a sort of link and way, which connects earthly things to the celestial ones, and it is as favourable to the stars as to the Elements' [translated by the author]

The scientific knowledge, although faithful to the thought of the Church of the sixteenth century, merges with the spiritual and mystical force that Guarini wanted to infuse in the architecture of the Holy Shroud and Saint Laurence.

Guarini, in his text Caelestis Mathematicae, shows his belief in the Ptolemaic system. The Ptolemaic system is functional for the Church, and it is a necessary and sufficient condition in order to solve relations inherent in its project of light-space-architecture with geometric constructions. The light guide, steadily, prayer and the discovery of the divine throughout the day. The whole architecture of the San Lorenzo, like a single body, responds to the solar and lunar laws.

The survey of the light path carried out on-site in the summer solstice and compared in the three-dimensional model of architecture. In the days of the summer solstice, the sunrise lights illuminate the entrance to the hall and the Annunciation Chapel. In the sixth hour (or 12.00), the sun simultaneously illuminates the God of Days, that is represented above the vault of the Nativity chapels, and the Father God on the Immaculate chapel. Also, an axis dotted with light enlivens the star is located at the centre of the floor of the hall, the altar, the altarpiece of San Lorenzo and the small dome of the Sancta Sanctorum. At sunset, the openings of the presbytery illuminate the star and the entrance, and those of the class-church frame the Crucifix chapel, lighting the Christ blessing with the globe and the dove of the Holy Spirit. 
The day light-cycle manifests the coming of Christ on earth, a man among men, and his assumption into heaven, son of God and God himself in the unity with the Father.

Guarini texts highlight the architect's interest in lunar motions. In the Caelestis Mathematicae, that was published in Turin in I683, various chapters deal with the Moon; in particular, the Tractatus III Expensio III and IV delve into the De lunaris mense e anno and the De ciclis lunaribus. The same model of the class-church drawing is similar to the scheme of the eight lunar phases. We can find iconic references to the moon the crescent moon in the hands of an angel in the Annunciation chapel or the iconography of the Virgin Immaculate.

The lunar or synodic month is cyclical every 19 years, the Metonic cycle. For the analysis, we chose the contemporary Metonic period of the church construction and each month some of the recurrences are related to the Marian worship and the equinoxes and solstices, and only at night. For example, the virtual verification of lunar events, in the examination of the year 167I, shows that on May 17, Pentecost and Upper Lunissit, the crescent Moon illuminates the evangelist San Luca, placed on the Chapel of the Annunciation. On the decoration of the arch of the Chapel, as already mentioned, an angel is carrying a crescent moon as a symbol of prosperity. On the day of the nativity, December 25, the moon, the last quarter, illuminates the hidden compartment of the chapel of the Crucifix. In the same year, the moon highlights the birthday as a man, the passage day of earthly life to the divine, and the transfiguration day as a child of God.

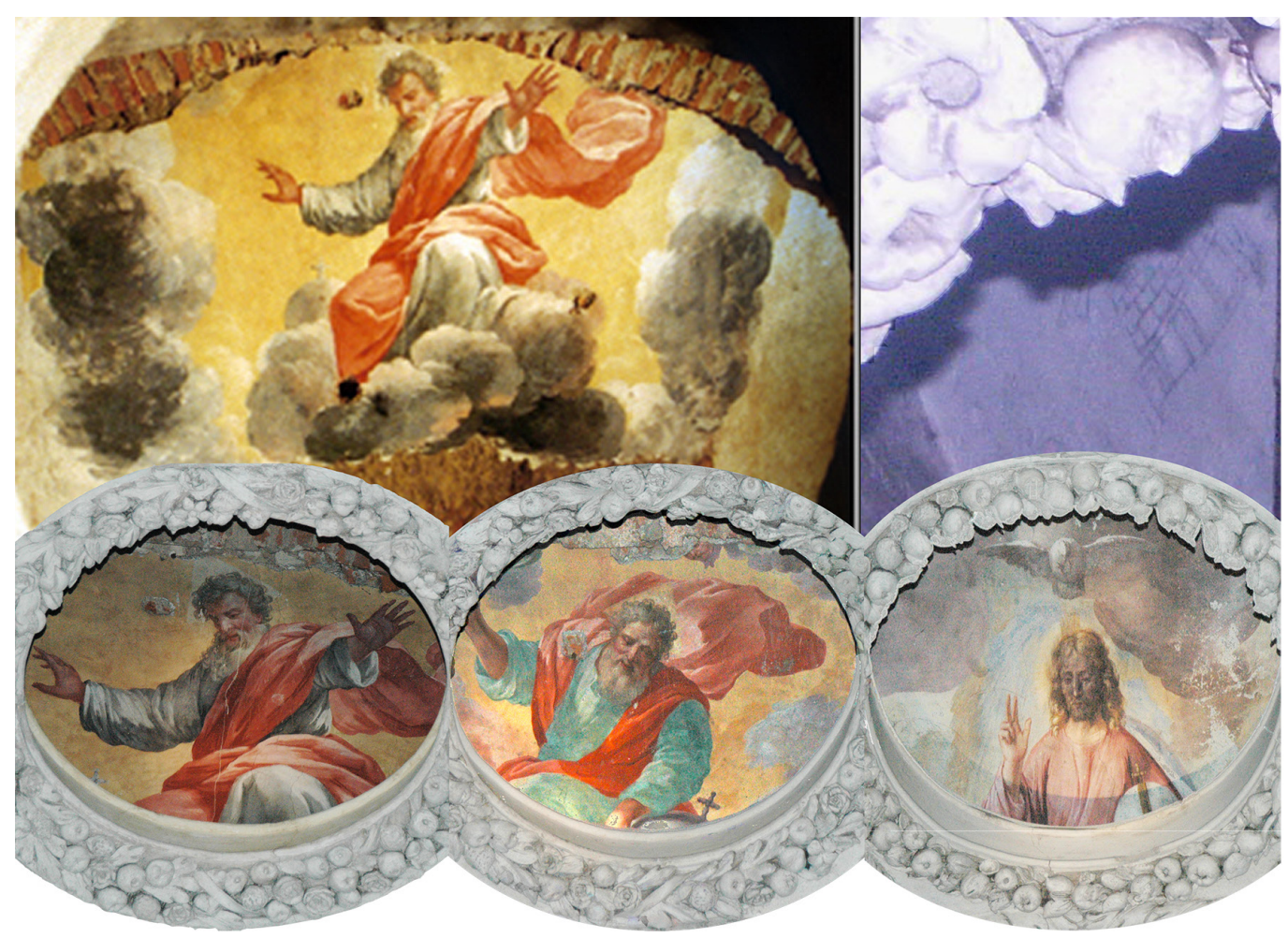

\section{Conclusions}

Guarini, an exegete of the Vitruvian lesson, renders architecture as a synthesis of the arts, this is a manifest-icon for religious tension towards God; he is hermeneutic of the reductio artium by Saint Bonaventure. Besides, he manifests the unity of the arts "under the light of revealed truth", and he elects architecture as his simulacrum. 
The San Lorenzo nave is the Prometheus triumph. Theory and Technique of arts, to realise a substantial Metis of the consolidated wall structures in performing structures of Light. The nave is a Metis of the paradoxical oral narration in an incredible evocative building.

Theory and Technique to achieve an imperishable Mnemosyne through the empirical narrative of Mary at the Nativity and Resurrection of Christ, for to continuous supported the transcendent Truth of the dogmas of faith with the wise virtual representation of the transcendent Light through the phenomena control of the immanent light.

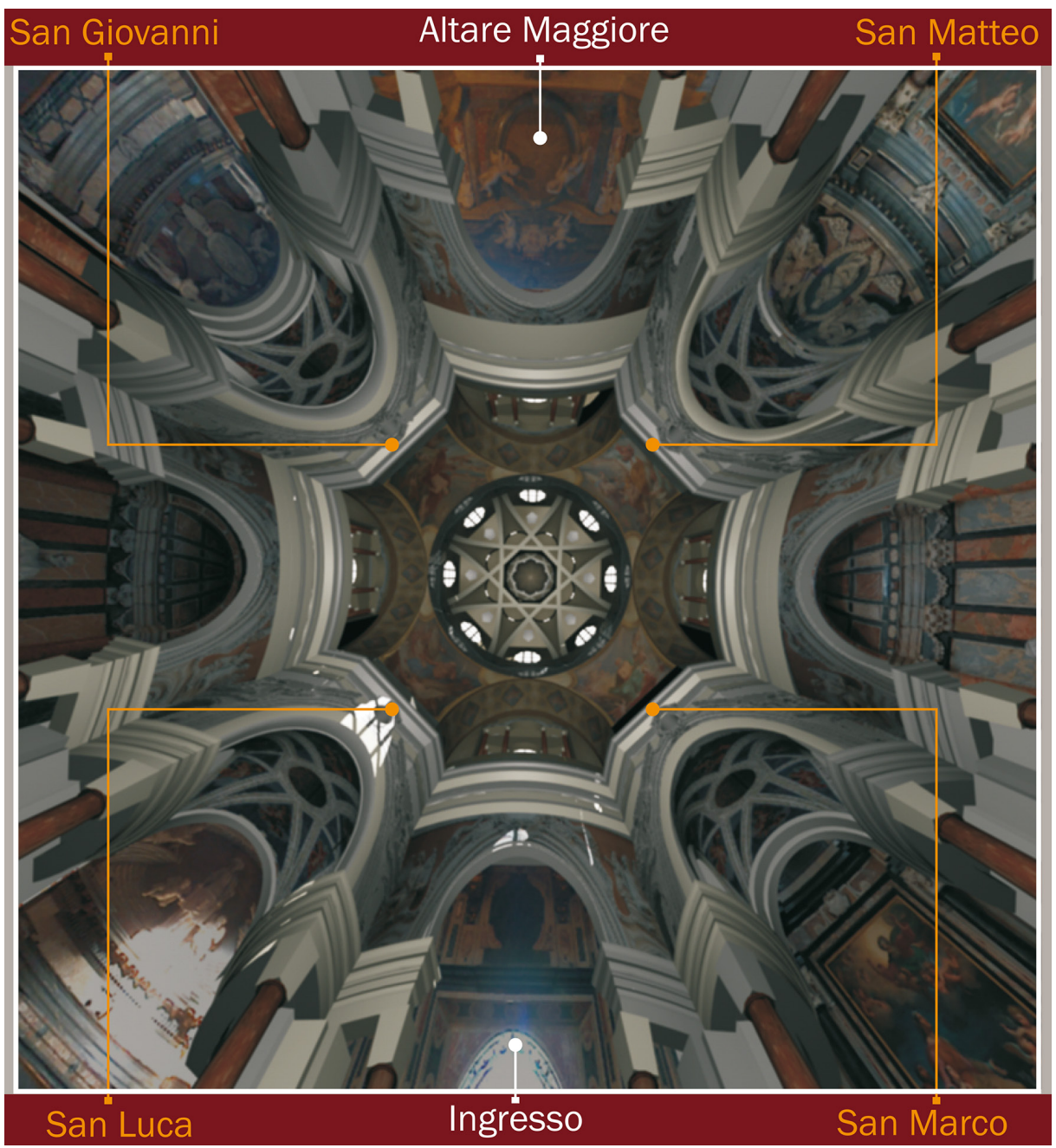

Notes

[I]The quotes and references by John Beldon Scott (2006), pp. I I7-I 22.

[2] <https://it.wikipedia.org/wiki/Esoterismo>.

[3] The quotes and references by Frascarelli (200I), pp. “Drape ... precious things for the service of the Divine Worship, ... the precious ornaments of the churches ... to increase pity in peoples, and reverence for the things of God." Even if the house is cramped, the cell is poor, the food is scarce, the dress is torn, but the church is rich and adorned" [Frascarelli 200 I, p. I6; Forti 1686, pp. I 85- 186.]. This is the thought of San Gaetano da Thiene, expressly shared by Carlo Borromeo in his lecture delivered in Olginate in 1583: "At least in worship, you were splendid, o children, [...] Because we instead do not remove something from our canteens, to embellish the house of God and expand our mother? [...]The sacred vessels would be of silver and gold, the altars covered with precious decorations". Johannes Molanus, in 1570, writes: "The church is an image of heaven on earth. God fills it in full. How can we not adorn it with what is most precious?" [Molanus I570, p. 24]. 


\section{References}

Ardissino Erminia (200 I). Il Barocco e il Sacro. Città del Vaticano: Libreria Editrice Vaticana, p. 6 I.

Aresi Paolo (|6| I). Arte di predicar bene.Venezia: Ciotti e Compagni, pp. 6, 7.

Argan Giulio Carlo (1957). L'architettura barocca in Italia. Milano: Garzanti, pp. 6I-63.

Argan Giulio Carlo (1970). La tecnica del Guarini. In Guarino Guarini e l'internazionalità del Barocco. Atti del Convegno internazionale promosso dall' Accademia delle Scienze di Torino. Torino, 30 settembre -5 ottobre, 1968. Torino: Accademia delle Scienze, voll, pp. 35-46.

Battisti Eugenio (1968). Schemata nel Guarini. In Guarino Guarini e l'internazionalità del Barocco:Atti del Convegno internazionale promosso dall' Accademia delle Scienze di Torino. Torino, 30 settembre -5 ottobre, 1968. Torino: Accademia delle Scienze, vol l, p. 109.

Beldon Scott John (1995). Guarino Guarini's Invention of the Passion Capitals in the Chapel of the Holy Shroud. In Journal of the Society of Architectural Historians, Vol. 54, N. 4, University of California Press: Berkeley, p. 4l 8-445.

Beldon Scott John (2006). "Stupire gl'intelletti”: Guarini e il significato dell'architettura. In Dardanello Giuseppe, Klaiber Susan, Millon Henry A. (a cura di). Guarino Guarini.Venezia: Centro Internazionale di Studi di Architettura Andrea Palladio, pp. I 17 - 121.

Crescenzi Carmela (2007). II modello e la complessità architettonica del San Lorenzo di Guarino Guarini. In: Docci Mario (a cura di). Metodologie integrate per il rilievo, il disegno, la modellazione dell'architettura e della città. Roma: Gangemi, pp. I 0 I - I04.

Crescenzi Carmela (2007). II San Lorenzo di Guarino Guarini. Rilievo integrato: interpretazione dei dati e rappresentazione (I). In Mandelli Emma (a cura di). Dati, informazione, Conoscenza. Metodi e tecniche integrate di rilevamento. I modelli tridimensionali, la costruzione e trasmissione dei dati. Firenze: Alinea, pp. 73-82.

Crescenzi Carmela (20I0). II San Lorenzo di Guarino Guarini. Rilievo integrato: interpretazione dei dati e rappresentazione (II). In Chiavoni Emanuela, Paolini Priscilla (a cura di). Metodi e Tecniche Integrate Di Rilevamento Per La Realizzazione Di Modell Virtuali Dell'architettura Della Città. Roma: Gangemi Editori, pp. 266-27I.

Crescenzi Carmela (20 I0). La Real Chiesa di San Lorenzo. L'architettura della struttura. In: Mandelli Emma,Velo Ulivia. II modello in architettura: tra cultura scientifica e rappresentazione. Firenze: Alinea, pp. 83-92.

Crescenzi Carmela et al. (2005). The survey of the baroque interior of the San Lorenzo Church in Turin. In: XX International Symposium. International cooperation to save the world's cultural Heritage. The International Archives Of The Photogrammetry Remote Sensing And Spatial Information Sciences, 26 september/I october 2005, Torino: CIPA vol. I, pp. $203-208$.

Dardanello Giuseppe ( 1993). La scena Urbana in Torino, 1675- 1699. In Giovanni Romano. Strategie e conflitti del Barocco. Torino: Cassa Risparmio Torino.

De la Brosse Olivier (1979). Lo spirito del barocco. Le Message Spirituel des Artistes à Rome. Roma: Centre Saint Louis de France. <http://www.gliscritti.it/arte_fede/barocco.htm>.

Frascarelli Dalma (200I). Arte e Controriforma: l'altare maggiore nelle Instructiones. Fabricae et supellectilis ecclesiasticae di Carlo Borromeo. In Marco Gallo. Cardinali Di Santa Romana Chiesa collezionisti e mecenati. Roma: Edizioni dell'Associazione Culturale Shakespeare And Company,Vol. I, pp. 24-37.

Guarini Guarino (1675). Compendio sulla sfera celeste. Torino: Giorgio Colonna.

Guarini Guarino (1683). Caelestis mathematicae pars prima (secunda), in qua leges antiquae, et nouae temporum. ExTypogrphia Ludouici Montiae.

Guarini Guarino (1737). Architettura civile. Appresso Gianfrancesco Mairesse. Torino.

Guarini Guarino (1665). Placita Philosophica. Paris: edizioni Thiery.

Gurlitt Cornelius (1887). Hichte dts Barockstilu in Italien. Ebner \& Seubert: Stuttgart.

Jungmann Josef Andreas (1962). La vita liturgica nel Barocco. In Jungmann Josef Andreas. Eredità liturgica e attualità pastorale. Roma: Paoline, pp. I33-145

Klaiber Susan (1993). Guarino Guarini's Theatine Architecture. New York: Columbia University.

Pérez-Gómez Alberto (1983). Architecture and the Crisis of Modern Science. Cambridge:The MIT Press.

Tavassi La Greca Bianca (1968). La posizione del Guarini in rapporto alla cultura filosofica del tempo. In Carboneri Nino, Tavassi La Greca Bianca. Guarino Guarini, Architettura Civile. Milano: Edizioni il Polifilo, pp. 440-455.

Wittkower Rudolf (1972). Arte e Architectura in Italia l600-1 750. Einaudi:Torino 1972 (ed. originale 1958).

\section{Author}

Carmela Crescenzi, Università di Firenze, carmela.crescenzi@unifi.it

To cite this chapter. Crescenzi CAamela (2020). Mutatis mutandis, architettura e narrazione. L'arte di Guarino Guarini/Mutatis mutandis, architecture and narrative. The Guarino Guarini skill. In Arena A., Arena M., Brandolino R.G., Colistra D., Ginex G., Mediati D., Nucifora S., Raffa P. (a cura di). Connettere. Un disegno per annodare e tessere. Atti del $42^{\circ}$ Convegno Internazionale dei Docenti delle Discipline della Rappresentazione/ Connecting. Drawing for weaving relationships. Proceedings of the 42th International Conference of Representation Disciplines Teachers. Milano: FrancoAngeli, pp. II19-1138 